\title{
Soil Structure and Moisture Constants Changed by Tobacco Waste Application in a Clay Textured Field
}

\author{
Coșkun GÜLSER* \\ Ondokuz Mayıs University, Faculty of Agriculture, Soil Science \& Plant Nutrition Dept. Samsun-TURKEY \\ *Corresponding author e-mail : cgulser@omu.edu.tr \\ Received : 17.03.2021 \\ Accepted : 14.06.2021 \\ DOI: $10.21657 /$ topraksu. 898853
}

\begin{abstract}
In this study, effect of tobacco waste (TW) application on soil structural parameters and water holding capacity were determined in a clay field. Tobacco waste was applied into a clay soil surface $(0-15 \mathrm{~cm})$ with 4 different rates $(0,2,4$ and 6\%) and three replications in a randomized plot design. After eight months, changes in soil organic carbon content, bulk density (BD), total porosity (F), gravimetric (W) and volumetric $(\theta)$ water content, air filled porosity (Fa) and relative saturation (RS) values were determined in clay soil for each treatment. TW application rates significantly increased organic C contents and F values while they significantly decreased bulk density values of the clay soil. Although the W values significantly increased over the control, the $\theta$ and RS values decreased with increasing the $F$ values by the application of TW. The high application rates of TW (4 and 6\%) increased moisture content at permanent wilting point (PWP) more than at field capacity (FC). Thus, AWC values in higher rates of TW were lower than the AWC values in $2 \%$ rate of TW and control treatments. Increasing Fa is important for plant root respiration and microbial activity especially in the clay soils. The high rates of TW increased F values but decreased the AWC of clay soil over the control treatment.
\end{abstract}

Key words: Tobacco waste, clay soil, structure, field capacity, wilting point, relative saturation.

\section{Kil Bünyeli Bir Arazide Toprak Strüktürü ve Nem Sabitlerinin Tütün Atığı Uygulamasıyla Değișimi}

Öz

Bu çalıșmada, tütün atığı (TW) uygulamasının kil bünyeli bir arazide toprak strüktürü ve su tutma kapasitesine etkisi belirlenmiștir. Tütün atığı kil bünyeli toprak yüzeyine $(0-15 \mathrm{~cm}) 4$ farklı oranda $(\% 0,2$, 4 ve 6) ve tesadüf parselleri denme deseninde üç tekrarlamalı olarak uygulanmıștır. Sekiz ay sonra, toprak organik karbon içeriği, hacim ağırlığı (BD), toplam gözeneklilik (F), gravimetrik (W) ve hacimsel $(\theta)$ su içeriği, hava dolu gözeneklilik (Fa) ve nispi doygunluk (RS) değerlerindeki değișimler belirlenmiștir. Tütün atığı uygulama oranları, killi toprağın hacim ağırlığı değerlerini önemli ölçüde düșürürken, organik C içeriği ve F değerlerini önemli ölçüde artırmıștır. Gravimetrik nem değerleri kontrole göre önemli ölçüde artmasına rağmen, TW uygulaması ile $F$ değerlerinin artması ile $\theta$ ve RS değerleri azalmıștır. TW'nin yüksek uygulama oranlarında (\%4 ve \%6), devamlı solma noktası (PWP)'daki nem içeriğini tarla kapasitesi (FC)'ne göre daha fazla arttırmıștır. Böylece daha yüksek TW oranlarındaki yarayıı̦lı nem (AWC) değerleri, \%2 TW dozu ve kontrol uygulamalarındaki AWC değerlerinden daha düșük olmuștur. Özellikle killi topraklarda Fa'nın artıșı bitki kök solunumu ve mikrobiyal aktivite için önemlidir. Yüksek TW oranları, F değerlerini artırmıș, ancak kontrol muamelesine göre killi toprağın AWC'sini azaltmıștır.

Anahtar Kelimeler: Tütün atığı, kil bünyeli toprak, strüktür, tarla kapasitesi, solma noktası, nispi doygunluk. 


\section{INTRODUCTION}

The intensive agricultural practices have significant effects on soil degradation through loss of soil organic matter, decline of soil structure, resulting soil compaction and root growth (Usowics and Lipiec, 2009; Busscher and Bauer, 2003). Agricultural waste treatments affect soil hydraulic properties due to mineralization of organic matter in soil (Gülser and Candemir, 2015). Gülser et al., (2017) found that application of hazelnut husk into a sandy clay loam soil increased OC content, basal soil respiration, saturated hydraulic conductivity and aggregate stability during the 16 weeks of incubation. They also determined that basal soil respiration as an indicator of soil microbial activity had significant positive correlations with $\mathrm{OC}$, aggregate stability and total soil porosity. Demir and Gülser (2021) reported that the rice husk compost treatments in the field and greenhouse conditions had positive effects on soil properties with increasing organic matter content, electrical conductivity, field capacity, permanent wilting point, available water content and reducing soil $\mathrm{pH}$ and soil bulk density over the control. A measure of soil microstructure can be an index of soil physical quality that is consistent with observation on soil compaction, on effects of soil organic matter content and on root growth (Dexter, 2004). Organic waste application into soil causes changes in soil structure and aggregate size distribution with increasing pore and aggregate sizes in bulk soil (Gülser et al., 2015). Soil compaction, occurs usually loss or reduced in size of the largest pores, increases soil bulk density and soil strength, and decreases macro porosity, soil water infiltration and water-holding capacity (Dexter, 2004).

There is a close interrelationship between bulk density and porosity with porosity decreasing as bulk density increases. The lower porosity provides poor aeration, which often is associated with reduced plant growth and, at times, may be related to certain soilborne plant diseases (Miller and Donahue, 1995; Selvi et al., 2019). Gülser and Candemir (2012) found that bulk density, relative saturation and penetration resistance decreased while mean weight diameter, total porosity, gravimetric water and organic matter contents of a clay soil increased with increasing application rates of agricultural wastes. They also reported that while the lowest penetration (0.72 MPa) was determined in 6\% doses application of hazelnut husk including the highest $\mathrm{C}: \mathrm{N}$ ratio, the highest penetration (1.72 MPa) was in the control soil. Weil and Magdoff (2004) reported that organic matter increases the soil's capacity to hold water by direct absorption of water and by enhancing the formation and stabilization of aggregates containing an abundance of pores that hold water under moderate tensions.

Tobacco is one of the most important agricultural products in the Black Sea region of Turkey. There are large quantities of tobacco wastes around this region. Recycling organic wastes in soil is important to help reducing the greenhouse gas emission from agricultural production areas. There is a little information about the effect of tobacco waste application on soil physical properties. Therefore, effect of tobacco waste (TW) application on soil structural parameters and water holding capacity were determined in a clay field in this study.

\section{MATERIAL AND METHODS}

A field experiment was conducted at the Experimental Field of Agricultural Faculty in Ondokuz Mayıs University, Samsun. The long term climatic data of mean air temperature and precipitation for Samsun is given in Table 1. The annual mean air temperature is $13.13{ }^{\circ} \mathrm{C}$ and annual total precipitation is $936 \mathrm{~mm}$ in Samsun.

Table 1. Climatic data for Samsun (https://tr.climate-data.org/asya/tuerkiye/samsun/samsun-268).

Çizelge 1. Samsun ili iklim verileri

January February March April May June July August September October November December

\begin{tabular}{ccccccccccccc}
\hline $\begin{array}{c}\text { Mean. } \\
\text { Temp. }\left({ }^{\circ} \mathrm{C}\right)\end{array}$ & 4.5 & 5.2 & 7.2 & 10.6 & 15 & 19.3 & 22 & 22.7 & 19.2 & 15 & 10.5 & 6.4 \\
\hline $\begin{array}{c}\text { Precipitation } \\
(\mathrm{mm})\end{array}$ & 85 & 77 & 97 & 87 & 87 & 64 & 43 & 43 & 74 & 96 & 85 & 98 \\
\hline
\end{tabular}


Tobacco waste (TW) was mixed into surface soil $(0-15 \mathrm{~cm})$ using a hoe with $0,2,4$ and $6 \%$ of dry weight basis with three replications in a completely randomized plot design on October 2002. There was no plantation until the soil sampling time and after eight months, some physical characteristics of the soil were determined in the soil samples taken from $15 \mathrm{~cm}$ soil depth before planting. After determining the $\mathrm{BD}$, total porosity $(\mathrm{F})$ was calculated by $F=1-B D / 2.65$, volumetric water content $(\theta)$ values were determined multiplying natural moisture (gravimetric water, W) content of soil samples by the bulk densities $(\theta=\mathrm{W}$. BD/ density of water). The relative saturation (RS) values were calculated dividing volumetric water contents by total porosity values (RS= $\theta / F)$. Air filled porosity was calculated subtracting volumetric water content from total porosity $(\mathrm{Fa}=\mathrm{F}-\theta)$. Moisture contents at the field capacity (FC) and the permanent wilting point (PWP) were determined equilibrating soil moisture of the saturated samples on the ceramic pressured plates at $33 \mathrm{kPa}$ for 24 hours and 1500 kPA for 96 hours, respectively (Demiralay, 1993). Soil reaction $(\mathrm{pH})$, electrical conductivity, and organic carbon content were determined according to Kacar (1994). According to the soil physical and chemical properties, the results can be summarized as; the textural class is clay $(56 \%)$, none saline $(0.60 \mathrm{dS} / \mathrm{m})$, neutral in $\mathrm{pH}(7.00)$, moderate in organic matter (3.4\%) (Soil Survey Staff, 1993). Statistical analysis of the results was done by standard analysis of variance, pairs of mean values compared by Duncan test using SPSS 17

\section{RESULTS AND DISCUSSIONS}

The application of TW increased organic matter content in the $0-15 \mathrm{~cm}$ soil layer (Table 2). The increments in mean values of OC content with the application rates were significantly different from the control $(P<0.01)$. Tobacco waste treatment decreased the bulk density values and increased total porosity values significantly $(P<0.05)$. The increments in total porosity with the application rates were

Table 2. The effect of tobacco waste (TW) application on soil organic $C(O C)$, bulk density (BD), total porosity (F) and gravimetric (W) water contents.

Çizelge 2. Tütün atığı (TW) uygulamasının toprak organik C (OC), hacim ağırlığı (BD), toplam gözeneklilik (F) ve gravimetrik (W) nem içeriklerine etkisi.

\begin{tabular}{ccccc}
\hline Treatments & OC, $\%$ & BD, g/cm & $F, \%$ & $W, \%$ \\
\hline TW 0\% & $1.99 \mathrm{c}^{* *}$ & $1.11 \mathrm{a}^{*}$ & $58.26 \mathrm{~b}^{*}$ & $35.99 \mathrm{~b}^{*}$ \\
\hline TW 2\% & $2.85 \mathrm{bc}$ & $1.01 \mathrm{ab}$ & $61.78 \mathrm{ab}$ & $33.07 \mathrm{~b}$ \\
\hline TW 4\% & $3.77 \mathrm{ab}$ & $0.89 \mathrm{~b}$ & $66.38 \mathrm{a}$ & $33.62 \mathrm{~b}$ \\
\hline TW 6\% & $4.29 \mathrm{a}$ & $0.89 \mathrm{~b}$ & $66.25 \mathrm{a}$ & $41.44 \mathrm{a}$ \\
\hline
\end{tabular}

**significant at 0.01 level, *significant at 0.05 level.

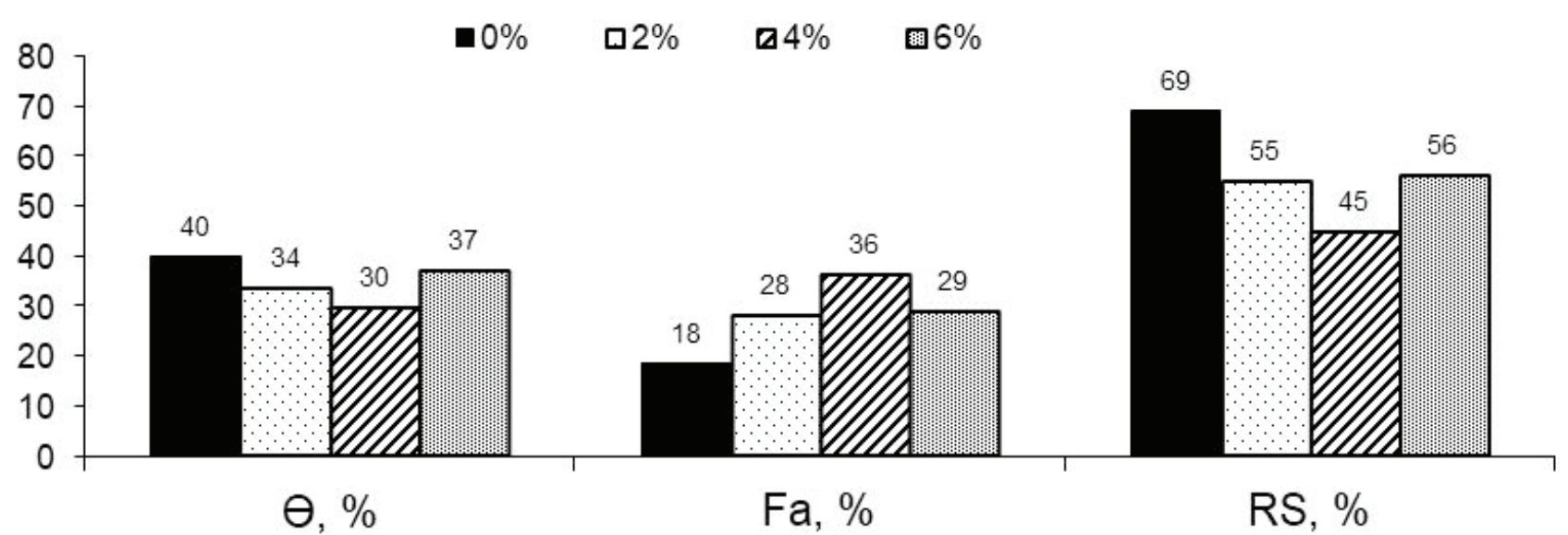

Figure $\mathbf{1}$. The effects of tobacco waste application doses on volumetric water content $(\theta)$, air filled porosity (Fa) and relative saturation (RS).

Șekil 1. Tütün atığı uygulama dozlarının hacimsel su içeriği ( $\theta$ ), hava dolu gözenekler (Fa) ve nispi doygunluk (RS) üzerine etkileri. 
significantly different from the control application $(P<0.05)$. In many studies, it is reported that addition of organic wastes into soils reduces bulk density and increases total porosity (Anikwe, 2000; Marinari et al., 2000; Candemir and Gülser, 2011). Although the gravimetric water contents (W) increased according to the control significantly $(P<0.05)$, the volumetric water contents $(\theta)$ decreased due to reducing bulk densities by the application of TW (Figure 1). The relative saturation values also decreased with increasing the application rates of tobacco waste (Figure 1). Generally, increments in the total porosity caused decreases in the RS. Although the highest moisture content (41.44\%) was determined in 6\% of TW treatment, the lower RS values were found with the TW treatments due to having higher total porosity values (Table 2). Increasing the application rates of tobacco waste increased the Fa compared to the control treatment (Figure 1). According to the control treatment, increases in mean Fa values by the TW treatments were obtained in the following order; TW2\% (28\%) < TW6\% (29\%) < TW4\% (36\%). Candemir and Gülser (2011) reported that increasing aeration due to aggregation occurred by the organic waste application caused increases in basal soil respiration or microbial activity in clay soil.

While TW application rates increased FC values insignificantly, PWP values significantly increased by increasing the application rates of TW $(P<0.05)$ compared to the control treatment (Figure 2). The highest FC (40.1\%) and PWP (31.2\%) were determined with $6 \%$ application rate of TW. The highest AWC (10,9\%) was determined in $2 \%$ of
TW application while the lowest AWC (8.1\%) was determined in 4\% rate of TW application (Figure 2). Addition of organic matter to soils increases water holding capacity (Gupta et al., 1977; Candemir and Gülser, 2011; Mamedov et al., 2016). Addition of higher rates of TW (4 and 6\%) in a clay soil increased PWP values more than FC values. Therefore, AWC values in higher dose applications of TW (4 and 6\%) were found lower than the AWC values in $2 \%$ of TW and control treatments.

Soil organic $C$ content had the significant positive correlations with $F\left(0.818^{* *}\right)$, Fa $\left(0.675^{*}\right)$, PWP $\left(0.850^{* *}\right)$, and significant negative correlations with BD $\left(-0.818^{* *}\right)$, RS $\left(-0.622^{*}\right)$ and AWC $\left(-0.630^{*}\right)$ (Table 3). Increasing soil organic $C$ content by the application of TW caused decreases in BD, $\theta$ and RS with increasing the total porosity. In many studies, it is indicated that soil organic matter content gives a significant negative correlation with bulk density and a significant positive correlation with total porosity (Candemir and Gülser, 2011; Gülser et al., 2016, Gülser et al., 2020). Demir and Gülser (2015) investigated the effects of rice husk compost on some soil quality parameters under greenhouse conditions. They reported that the highest positive correlations among the soil quality parameters were determined between OM and PWP $\left(0.924^{* *}\right)$, AWC and $\mathrm{FC}\left(0.907^{* *}\right), \mathrm{OM}$ and $\mathrm{FC}\left(0.897^{* *}\right), \mathrm{CO}_{2}$ and PWP $\left(0.862^{* *}\right)$, PWP and FC $\left(0.791^{* *}\right)$; while the highest negative correlations were found between $\mathrm{BD}$ and $\mathrm{FC}\left(-0.854^{* *}\right), \mathrm{BD}$ and PWP $\left(-0.871^{* *}\right), \mathrm{BD}$ and $\mathrm{OM}\left(-0.868^{* *}\right), \mathrm{BD}$ and $\mathrm{CO} 2\left(-0.838^{* *}\right), \mathrm{BD}$ and $P\left(-0.821^{* *}\right)$, Ca and FC $\left(-0.812^{* *}\right)$. Gülser (2006)

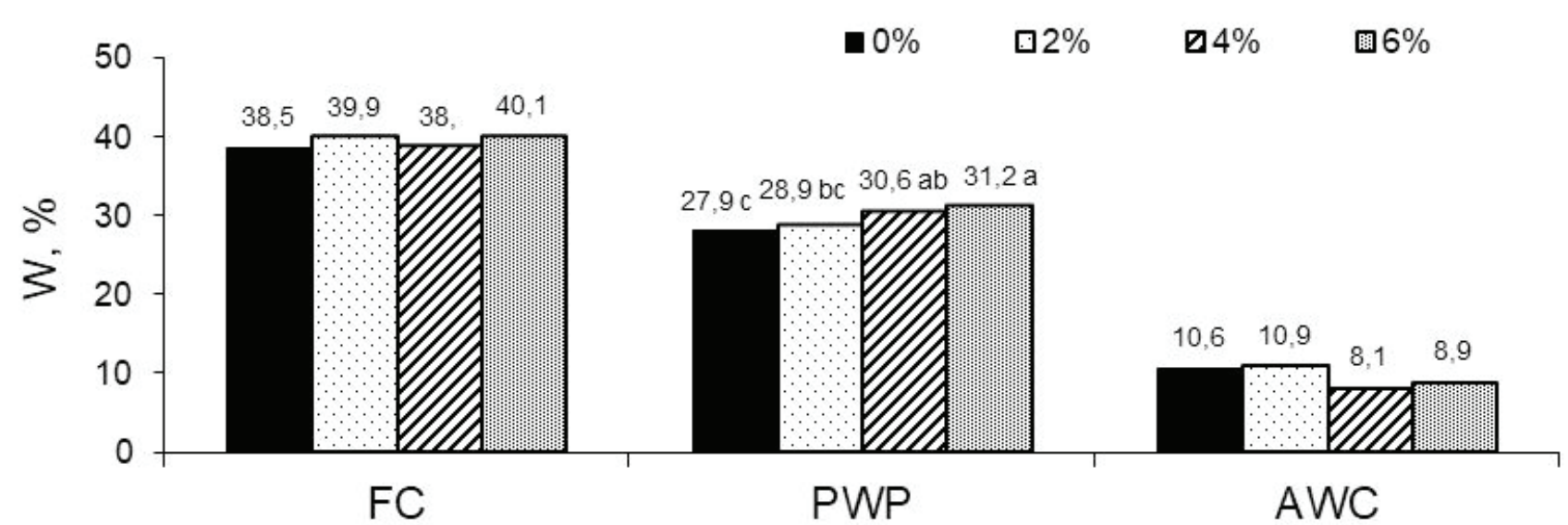

Figure 2. The effects of tobacco waste application rates on moisture content (W) at field capacity (FC), permanent wilting point (PWP) and available water content (AWC).

Şekil 2. Tütün atığı uygulama dozlarının tarla kapasitesi (FC), daimi solma noktası (PWP) ve yarayıșlı su (AWC) içeriğiindeki nem miktarın (W) üzerine etkileri., 
Table 3. The correlations among the soil properties.

Çizelge 3. Toprak özellikleri arasındaki korelasyonlar.

\begin{tabular}{|c|c|c|c|c|c|c|c|c|c|}
\hline & $\mathrm{BD}$ & W & $\theta$ & RS & $\mathrm{F}$ & $\mathrm{Fa}$ & FC & PWP & AWC \\
\hline $\mathrm{OC}$ & $-0.818^{* *}$ & 0.288 & -0.473 & $-0.622^{*}$ & $0.818^{* *}$ & $0.675^{*}$ & 0.199 & $0.850^{* *}$ & $-0.630^{*}$ \\
\hline $\mathrm{BD}$ & & -0.089 & $0.749 * *$ & $0.893 * *$ & $-1.000 * *$ & $-0.924 * *$ & -0.123 & $-0.675^{*}$ & 0.522 \\
\hline W & & & $0.592^{*}$ & 0.364 & 0.089 & -0.299 & 0.502 & 0.296 & 0.040 \\
\hline$\theta$ & & & & $0.965^{* *}$ & $-0.749 * *$ & $-0.946 * *$ & 0.215 & -0.357 & 0.444 \\
\hline RS & & & & & $-0.893 * *$ & -0.996 ** & 0.076 & -0.491 & 0.478 \\
\hline $\mathrm{F}$ & & & & & & $0.924 * *$ & 0.124 & $0.675^{*}$ & -0.521 \\
\hline Fa & & & & & & & -0.064 & 0.537 & -0.512 \\
\hline $\mathrm{FC}$ & & & & & & & & 0.131 & 0.484 \\
\hline PWP & & & & & & & & & $-0.805^{* *}$ \\
\hline
\end{tabular}

Correlation significant ** at 0.01 level, * at 0.05 level.

reported that increasing macroaggregation in a clay soil due to forage cropping caused increases in organic matter content in soil and decreases in bulk density values. In another study, Gülser (2004) found that increasing soil organic matter content decreased bulk density with increasing total porosity. Air filled porosity had significant positive correlation with $F\left(0.924^{* *}\right)$, and negative correlations with $\operatorname{BD}\left(-0.924^{* *}\right), \theta\left(-0.946^{* *}\right)$ and RS $\left(-0.996^{* *}\right)$. PWP also gave significant positive correlation with $F$ $\left(0.675^{*}\right)$, and significant negative correlations with $\operatorname{BD}\left(-0.675^{*}\right)$ and AWC (-0.805**). lqbal et al. (2005) studied spatial variability of OM, FC, PWP and AWC values and reported that increasing OM content in the field caused increases in FC and PWP values.

\section{CONCLUSION}

Addition of TW into the clay soil increased organic C content, F, Fa, FC and PWP by reducing RS and bulk density. According to the control treatment, decreases in RS and increases in F, Fa, FC and PWP by the different rates of TW were generally in the same order as follows; TW6\% > TW4\% > TW2\%. The different rates of TW had different effects on soil structural properties of clay soil with increasing organic matter content and reducing BD. It can be concluded that tobacco waste application had positive effects on improving soil structural properties. Although application of TW to the clay soil increased gravimetric water content over the control, air filled porosity increased with increasing $F$ and decreasing RS. It is important for plant root respiration and microbial activity especially in clay soils. The higher application dose of TW increased total porosity but decreased AWC of clay soil over the control treatment. The application dose of organic wastes, like a TW application, to clay soils should be selected carefully with considering the soil moisture characteristic curve behavior. Local agricultural wastes can be used as a soil conditioner to improve soil physical properties of soils located under similar climatic conditions of Black Sea Region.

\section{REFERENCES}

Anikwe MAN (2000). Amelioration of a Heavy Clay Loam Soil with Rice Husk Dust and its Effect on Soil Physical Properties and Maize Yield. Bioresource Technology 74: 169-173.

Busscher WJ, Bauer PJ (2003). Soil strength, cotton root growth and lint yield in a southeastern USA coastal loamy sand. Soil and Tillage Research 74: 151-159.

Candemir F, Gülser C (2011). Effects of different agricultural wastes on some soil quality indexes at clay and loamy sand fields. Communications in Soil Science and Plant Analysis 42 (1): 13-28.

Demir Z, Gülser C (2015). Effects of rice husk compost application on soil quality parameters in greenhouse conditions. Eurasian Journal of Soil Science 4 (3): 185-190.

Demir Z, Gülser C (2021). Effects of Rice Husk Compost on Some Soil Properties, Water Use Efficiency and Tomato (Solanum lycopersicum L.) Yield under Greenhouse and Field Conditions. Communications in Soil Science and Plant Analysis, 52 (9): 1051-1068. doi: 10.1080/00103624.2021.1892731.

Demiralay I (1993). Soil physical analysis. Ataturk Univ. Agric. Fac. Pub. No:143, Erzurum.

Dexter AR (2004). Soil physical quality Part I. Theory, effects of soil texture, density, and organic matter, and effects on root growth. Geoderma 120 (3-4): 201-214.

Gülser C (2004). A Comparision of some physical and chemical soil quality indicators influenced by different crop species. Pakistan Journal of Biological Sciences 7 (6): 905-911.

Gülser C (2006). Effect of forage cropping treatments on soil structure and relationships with fractal dimensions. Geoderma 131 (1-2): 33-44. 
Gülser C, Candemir F (2015). Effects of agricultural wastes on the hydraulic properties of a loamy sand cropland in Turkey. Soil Science and Plant Nutrition, 61 (3): 384-391.

Gülser C, Candemir F, Kanel Y, Demirkaya S (2015). Effect of manure on organic carbon content and fractal dimensions of aggregates. Eurasian Journal of Soil Science, $4(1)$ : 1.

Gülser C, Ekberli I, Candemir F, Demir Z (2016). Spatial variability of soil physical properties in a cultivated field. Eurasian Journal of Soil Science 5 (3): 192-200.

Gülser C, Minkina T, Sushkova S, Kızılkaya R (2017). Changes of soil hydraulic properties during the decomposition of organic waste in a coarse textured soil. Journal of Geochemical Exploration, 174: 66-69.

Gülser F, Salem S, Gülser C (2020). Changes in some soil properties of wheat fields under conventional and reduced tillage systems in Northern Iraq. Eurasian Journal of Soil Science, 9 (4): 314-320.

Gupta SC, Dowdy RH, Larson WE (1977). Hydraulic and Thermal Properties of a Sandy Soil as Influenced by Incorporation of Sewage Sludge. Soil Science Society America Journal 41: 601-605.

Iqbal J, Thomasson JA, Jenkins JN, Owens PR, Whisler FD, (2005). Spatial variability analysis of soil physical properties of alluvial soils. Soil Science Society of America Journal, 69: 1338-1350.
Kacar B (1994). Chemical analysis of plant and soil analysis. Ankara Univ. Faculty of Agriculture Publication No. 3 Ankara.

Mamedov A, Ekberli I, Gülser C, Gümüș I, Çetin U, Guy Levy GJ (2016). Relationship between soil water retention model parameters and structure stability. Eurasian Journal of Soil Science, 5 (4): 314-321.

Marinari S, Masciandar G, Ceccanti B, Grego S (2000). Influence of Organic and Mineral Fertilizers on Soil Biological and Physical Properties. Bioresource Technology 72: 9-17.

Miller RW, Donahue RL (1995). Soils in Our Environment, Seventh Edition. Prudence Hall, Englewood, Cliffs, NJ. p. 323.

Selvi KC, Gülser C, Beyhan MA (2019). Short Term Effects of Different Tillage Methods on Nitrate Content in Soil and Corn Yield. Malaysian Journal of Soil Science 23: 55-68.

Soil Survey Staff (1993). Soil Survey Manuel. United States Department of Agriculture (USDA) Handbook No:18, Government Printing Office, Washington, D.C. USA.

Usowics B, Lipiec J (2009). Spatial distribution of soil penetration resistance as affected by soil compaction: The fractal approach. Ecological Complexity 6: 263-271.

Weil RR, Magdoff $F$ (2004) Significance of soil organic matter to soil quality and health. In: Weil RR, Magdoff $F$ (eds) Soil organic matter in sustainable agriculture. CRC press, Florida, pp 1-43 